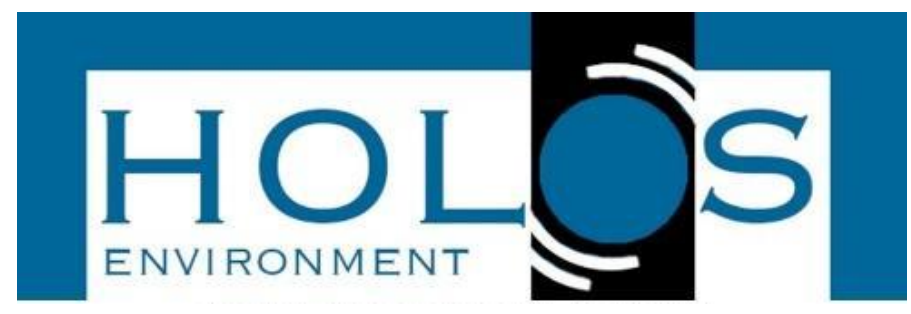

\title{
GROUNDWATER RECHARGE IN PHREATIC AQUIFERS, A CASE STUDY: MODELING UNSATURATED ZONE AND RECHARGE RATES OF THE RIO CLARO AQUIFER USING HYDRUS-1D
}

\section{RECARGA DE ÁGUAS SUBTERRÂNEAS EM AQUÍFEROS FREÁTICOS, UM ESTUDO DE CASO: MODELAGEM DA ZONA NÃO SATURADA E DE TAXAS DE RECARGA DO AQUÍFERO RIO CLARO USANDO HYDRUS-1D}

\author{
Guilherme E. H. Nogueira1; Roger D. Gonçalves²
}

Artigo recebido em: 13/10/2021 e aceito para publicação em: 30/11/2021.

DOI: http://doi.org/10.14295/holos.v21i3.12455

\begin{abstract}
The hydrological process in which water infiltrates from the soil surface to the top of saturated zone of an aquifer is called groundwater recharge. A better understanding of this process is one of the keys for a proper management of an aquifer system, especially in places where water supply relies solely on groundwater. This study presents the applicability of the one-dimensional mathematical model HYDRUS-1D® to simulate the unsaturated zone of the Rio Claro Aquifer, southeastern Brazil, in order to interpret the behavior of the aquifer recharge over time and under different rainfall regimes. Deriving out of simulations, the influence of different precipitation rates, as well as the effect of different land use on the recharge zones was assessed. Results enabled us to observe the variation of distinct properties of the soil profile, such as the spatio-temporal changes in hydraulic conductivity and soil moisture content at different soil horizons and depths due to flow and rainfall dynamics. Moreover, the average infiltration time from the soil surface to the top of saturated zone was estimated to be between 85-90 days. The precipitation/recharge ratio was at $20-30 \%$ intervals, presenting higher values in periods of greater precipitation. Likewise, changes in land use such as the increase in paved areas led to a nearly virtual zero recharge emphasizing the importance of uncovered areas for natural aquifer recharge processes.
\end{abstract}

Keywords: Groundwater recharge. Unconfined aquifer. Numerical modelling. Global change. UNESP Rio Claro.

Resumo: O processo hidrológico no qual a água infiltra a partir da superfície do solo até o topo da zona saturada de um aquífero é chamado de recarga subterrânea. Um melhor entendimento desse processo é uma das chaves para um gerenciamento adequado de um sistema aquífero, especialmente em locais onde o suprimento de água depende somente das águas subterrâneas. Este estudo apresenta a aplicabilidade de um modelo matemático unidimensional no HYDRUS-1D para simular a zona não saturada do Aquífero Rio Claro, região sudeste do Brasil, com o intuito de interpretar o comportamento da recarga subterrânea através do tempo e sob diferentes regimes de chuva. A partir das simulações, foi avaliada a influência de diferentes taxas de precipitação, assim como o efeito de diferentes usos do solo nas zonas de recarga. Os resultados permitiram observar a variação de propriedades distintas do perfil de solo, como as mudanças espaço-temporais na condutividade hidráulica e no teor de umidade do solo em diferentes horizontes e profundidades devido às dinâmicas de fluxo e precipitação. Ademais, o tempo médio de infiltração da água da superfície do solo até o topo da zona saturada foi estimado

\footnotetext{
1 UFZ - Helmholtz Centre for Environmental Research, Alemanha. E-mail: (guilherme.nogueira@ufz.de)

${ }^{2}$ Center for Environmental Studies and Basin Studies Laboratory, São Paulo State University, UNESP, Rio Claro, SP, Brazil. E-mail: (rdgon@hotmail.com)
} 
entre 85 e 90 dias. A razão precipitação/recarga permaneceu em intervalos de $20 \%$ a $30 \%$, apresentando os maiores valores nos períodos de maior precipitação. Da mesma forma, as mudanças no uso do solo, como o aumento das áreas pavimentadas, levaram as taxas de recarga a praticamente zero, enfatizando a importância das áreas não-pavimentadas para os processos de recarga natural dos aquíferos.

Palavras-chave: Recarga subterrânea. Aquífero livre. Modelagem numérica. Mudança global. UNESP Rio Claro.

\section{INTRODUCTION}

Most of available freshwater resources on our planet is located under the ground (approximately $98 \%$ of the total fresh water), stored as groundwater within porous and fractured aquifer systems, where it flows through the rock before discharging to streams, lakes or into the ocean (HÖLTING; COLDEWEY, 2019). Especially in the case of phreatic (or unconfined) aquifers, which are directly connected to the atmosphere through a porous soil column (different than confined aquifers), their water replenishment mainly occurs after water has infiltrated and travelled this soil profile (ŞEN, 2015, SPRENGER et al., 2016). The water flows through the so-called vadose zone, whereas water (and solutes) move downwards due to gravity and eventually reach the top of the saturated zone, leading to fluctuations on the water table. Because shallow phreatic aquifers are directly linked to the atmosphere through this porous media, they are strongly subjected to atmospheric dynamics, such as temperature and rainfall variations, which can lead to different evaporation, water uptake from plant-roots, and thus, different groundwater recharge rates (e.g., RAIDLA et al., 2016). Although they are highly susceptible to contamination and impacts from climate change, shallow aquifers are important and widely explored for water supply in the world.

To estimate groundwater recharge and the unsaturated zone travel-time, different methods and models can be applied. In this sense, analytical solutions (e.g., derivation of Boussinesq equation - Su, 1994), graphic methods (e.g., the Water Table Fluctuation method - HEALY, 2010; HEALY; COOK, 2002) or chemical and isotopic approaches (e.g., $\mathrm{Cl}$ method, $\mathrm{H}^{3}, \mathrm{O}^{18}$ - ALLISON et al., 1994; NOGUEIRA et al., 2019) are the more conventional techniques used nowadays. However, the use of numerical flow models is being increasingly applied given the growing computational capability available recently (BRANDENBURG, 2020). For the purpose of calculating 
groundwater recharge, one-dimensional mathematical models may be appropriately applied, by simulating the vertical flow of water through the vadose zone. In these hydrogeological models, recharge is represented by a change in the baseflow of the designed model, which represents the top of the saturated zone of the aquifer (i.e., the water table) (e.g., NETO et al., 2015). Still, estimating the recharge of an aquifer is one of the challenges faced when developing a hydrogeological model. Its restrictions and problems hover in the acquisition of parameters that are difficult to be monitored and/or evaluated, such as surface run-off, water evaporation and even root absorption (known as transpiration). Nonetheless, numerical models are a good alternative in order to estimate groundwater recharge because it overcomes the laborious effort of sampling techniques, for instance, whereas they also provide the opportunity to assess such process under different projections and other potential future scenarios (e.g., dos SANTOS et al., 2021, SPRENGER et al., 2016).

In this study, a one-dimensional model with a soil profile of $8.0 \mathrm{~m}$ was constructed using the HYDRUS-1D ${ }^{\circledR}$ software (ŠIMU゚NEK et al., 1998, 2008) to represent the vadose zone of the Rio Claro Aquifer in the area where natural recharge from rainfall is known to occur (NOGUEIRA; KIANG, 2015). The overall aims of this study are to: 1) obtain a better view on the recharge process of the Rio Claro Aquifer; and 2) assess the seasonal variations of the properties and characteristics of the local vadose zone. Moreover, generating different scenarios with diverse rainfall values allows us to evaluate the resulting recharge rates for each simulated scenario. With that, we are able to simulate the systematic decrease in rainfall, which has been reported in different places in the country and that is projected to be larger in the coming years (IPCC, 2021), and gauge the resulting effects on local groundwater recharge.

\section{MATERIALS AND METHODS}

\subsection{Study area}

The study area chosen for this modeling study was the campus of the São Paulo State University (UNESP), in Rio Claro - SP, Brazil, located in the eastern sector of the city. Rio Claro is located on the center-western portion of the São Paulo state, approximately $180 \mathrm{~km}$ from the capital city, Figure 1. 
Figure 1 - Location of the study area within regional and local contexts

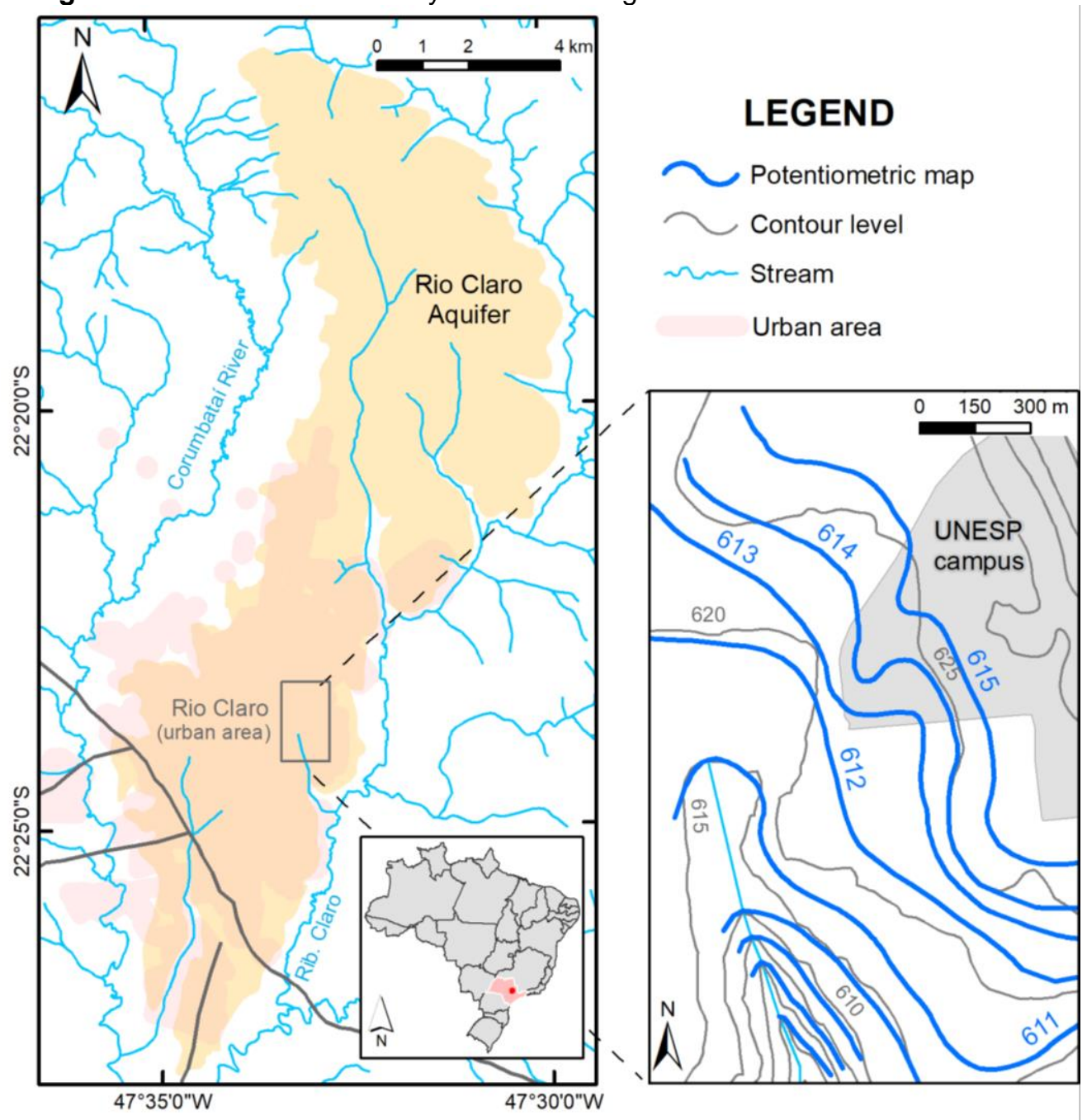

Source: Gonçalves et al. (2019).

Previous studies have showed that the surroundings of the campus is a recharge area for the aquifer, consisting of topographically high and flat portions and with little or no impermeable cover (GONÇALVES et al., 2019; NETO et al., 2015; NOGUEIRA; KIANG, 2015), thus allowing water from rainfall to infiltrate into the soil and reach the top of the saturated zone of the aquifer. The geology of the area is mainly composed by the poor selected sandy sediments from the Rio Claro Formation (OLIVA, 2006; GONÇALVES; CHANG, 2018). The formation presents diverse clayey and silt lenses and horizons, which gives it a rather silt-clayey hydrological characteristic (e.g., PERINOTTO et al., 2006; NOGUEIRA; KIANG, 2015). The 
formation presents a variable thickness and a deep pedogenetic alteration, which results in thick soil profiles in the area. Locally, the Fm. Rio Claro is in direct contact with the siltstones of the aquitard Corumbataí Formation.

The Rio Claro aquifer is a phreatic aquifer, storing water in fissures and in its porous interstices, with a rather shallow water table located at depths between 8 and 10 meters depending on the period of the year. The recharge of the aquifer is mainly linked to infiltrating water from rainfall, which is between $10-20 \%$ of total annual precipitation (approximately from $730 \mathrm{~mm} /$ year to $1400 \mathrm{~mm} /$ year) (GONÇALVES et al., 2019; NOGUEIRA; KIANG, 2015). The aquifer is largely exploited in the region of the municipality, including inside the UNESP campus, which increases the importance of an improved management and understanding of related recharge processes.

\subsection{Numerical modeling}

The representation of the vadose zone of the Rio Claro Aquifer is carried through the HYDRUS-1D ${ }^{\circledR}$ version 4.16.0 (ŠIMU゚NEK et al., 1998, 2008). HYDRUS$1 \mathrm{D}^{\circledR}$ simulates water flow and mass transport in saturated variable media, resolving the Richards Equation (Eq.1) through the Galerkin numerical solution, using the finite element method (FEM).

$\mathrm{q}=-\mathrm{K}(\theta)\left(1-\frac{\partial \Psi_{\mathrm{m}}}{\partial \theta} \frac{\partial \theta}{\partial \mathrm{z}}\right)$

$q=$ water flux $\left[L^{3} / T\right]$;

$\mathrm{K}(\theta)=$ non-saturated hydraulic conductivity $[\mathrm{L} / \mathrm{T}]$;

$\theta=$ volumetric water content [-];

$\psi_{\mathrm{m}}=$ matric potential of the soil [-];

$\mathrm{z}=$ local datum $[\mathrm{L}]$.

The matric potential of a media is related to the adhesion between water and the respective material and can be directly measured in the field through tensiometers, for instance. HYDRUS has a database of water parameters for non-saturated media based on the functions expressed by van Genuchten (1980), which allows for the calculation of $K(\theta)$, Eq.2: 
$K(\theta)=K_{s} \sqrt{\frac{\theta-\theta_{r}}{\phi-\theta_{r}}}\left[1-\left(1-\left(\frac{\theta-\theta_{r}}{\phi-\theta_{r}}\right)^{1 / m}\right)^{m}\right]^{2}$

$\mathrm{K}_{\mathrm{s}}=$ saturated hydraulic conductivity $[\mathrm{L} / \mathrm{T}]$;

$\theta_{\mathrm{r}}=$ residual volumetric water content $[-]$;

$\phi=$ porosity [-];

$m=$ empirical constant related to geological media, $m=1-1 / n$;

$\mathrm{n}=$ empirical constant related to grain size (e.g., 1 and 2 for fines, and $\geq 4$ for coarser).

The 8 meters of soil profile representing the local vadose zone were discretized in 400 nodes, with equal spacing of $0.02 \mathrm{~m}$ between them. Local hydrogeological parameters were derived from $\mathrm{K}_{\mathrm{s}}$ values according to Alfaro Soto et al. (2008). Six types of soil were considered within the simulated profile, as can be seen in Table 1.

Table 1 - van Genuchten-Mualem hydraulic parameters for the soil of the Rio Claro Formation according to soil depth

\begin{tabular}{|c|c|c|c|c|c|c|}
\hline Depth (m) & Or & Os & $\alpha\left(m^{-1}\right)$ & $\mathbf{n}$ & $K_{s}(m / d)$ & $\mathbf{L}$ \\
\hline $0-1.50$ & 0.039 & 0.387 & 3.34 & 1.42 & 0.53 & 0.5 \\
\hline $1.50-2.50$ & 0.043 & 0.386 & 3.11 & 1.40 & 2.76 & 0.5 \\
\hline $2.50-3.50$ & 0.046 & 0.385 & 2.94 & 1.39 & 3.78 & 0.5 \\
\hline $3.50-4.50$ & 0.050 & 0.387 & 2.57 & 1.39 & 4.36 & 0.5 \\
\hline $4.50-5.50$ & 0.056 & 0.386 & 2.66 & 1.37 & 0.498 & 0.5 \\
\hline $5.50-8.00$ & 0.057 & 0.386 & 2.63 & 1.36 & 0.991 & 0.5 \\
\hline
\end{tabular}

Fonte: Alfaro Soto et al. (2008).

The parameters $\alpha$ and $n$ are empirical factors relative to the retention curve to calculate actual water content on a media (GENUCHTEN, 1980); the parameter L represents the tortuosity of the fluid; the term $\theta$ r represents the residual water content, $\theta s$ is the saturated water content, and the Ks represents the saturated hydraulic conductivity of the material.

Numerical simulations were carried out covering a core period of seven years, between 01-Jan-2008 and 01-Jan-2015. A second set of simulations were performed 
covering a large time-period of ten years (from 01-Jan-2005 to 01-Jan-2015) in order to capture possible larger climate cycles and assess the resulting long-term groundwater recharge rates in comparison to shorter periods. Thus we can avoid potential biased results due to extreme climate conditions (e.g., dry years). At the top of the numerical model, atmospheric boundary conditions (BC) were imposed to represent daily precipitation and temperature variations for the simulated period. Daily rainfall (Figure 2) was acquired from the meteorological station of the Center for Environmental Studies and Planning at UNESP, located in the study area, and directly applied at the model top as the software independently computes other water redistribution and components (e.g., interception, runoff, evaporation, and actual infiltration) accordingly.

Figure 2 - Daily precipitation recorded for the site between 2005 and 2015.

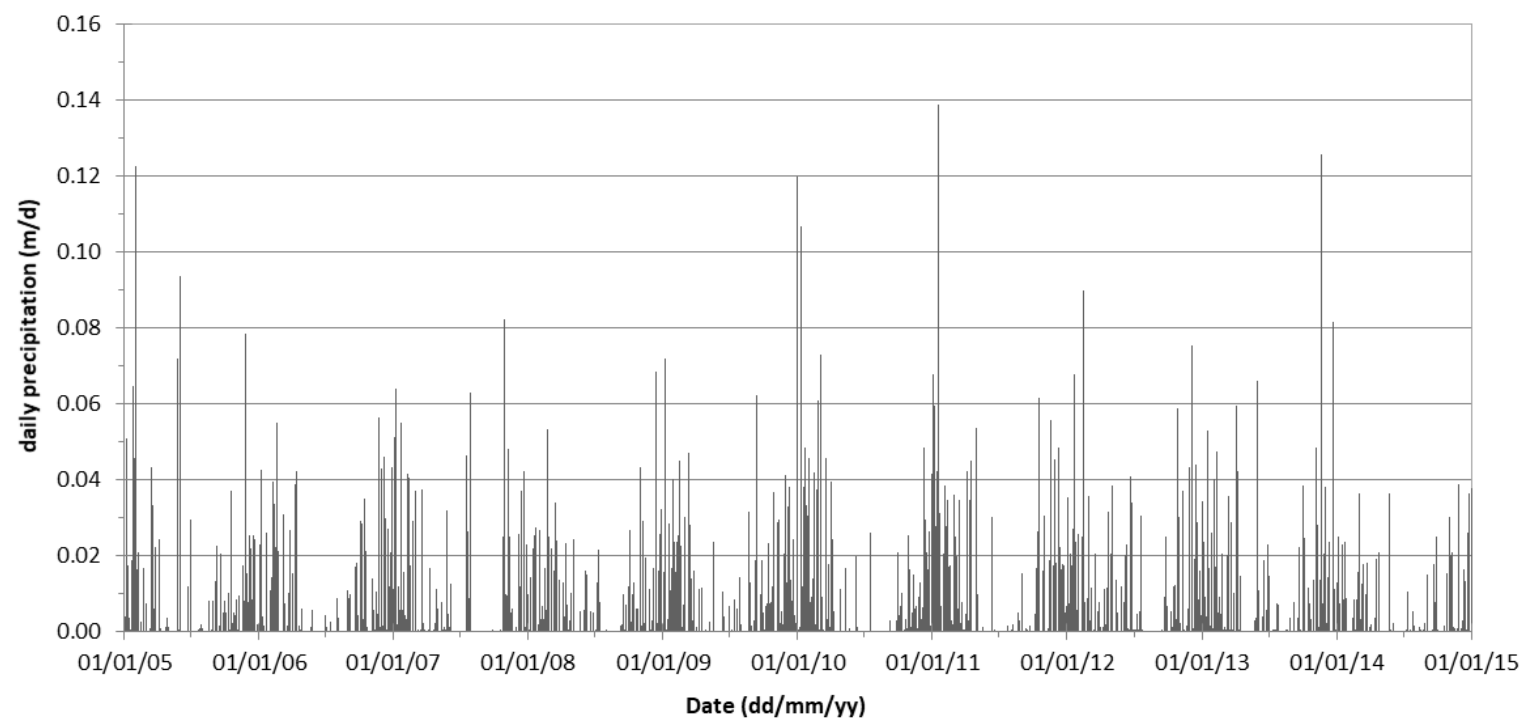

Additionally, at the top of the model an accumulation of up to $0.02 \mathrm{~m}$ of water was stipulated before run-off starts to represent what is expected for the site since the area presents very low topographic gradient and ponding water can occur to some extent. Root water uptake and evaporation were also represented in the model, following the functions of Hargreaves (1975) and Feddes et al. (1978), respectively, which are enclosed in the HYDRUS software. Vegetation cover was selected from the HYDRUS database as standard grass to approximate the conditions of the study area. The distribution of the roots was made in a linear shape from the soil surface (maximum value) up to $0.60 \mathrm{~m}$ deep (null value) and its hydraulic properties were based on the literature (FEDDES et al., 1978). Thus, evapotranspiration (ETP) rates in the model 
were implemented using the approximation of Hargreaves (1975) following the coordinates and elevation of the site (latitude of $22^{\circ} 24^{\prime}$ and altitude of $620 \mathrm{~m}$ ), in combination with the relations from Feddes et al. (1978) based on daily values of maximum and minimum air temperature, showed in Figure 3.

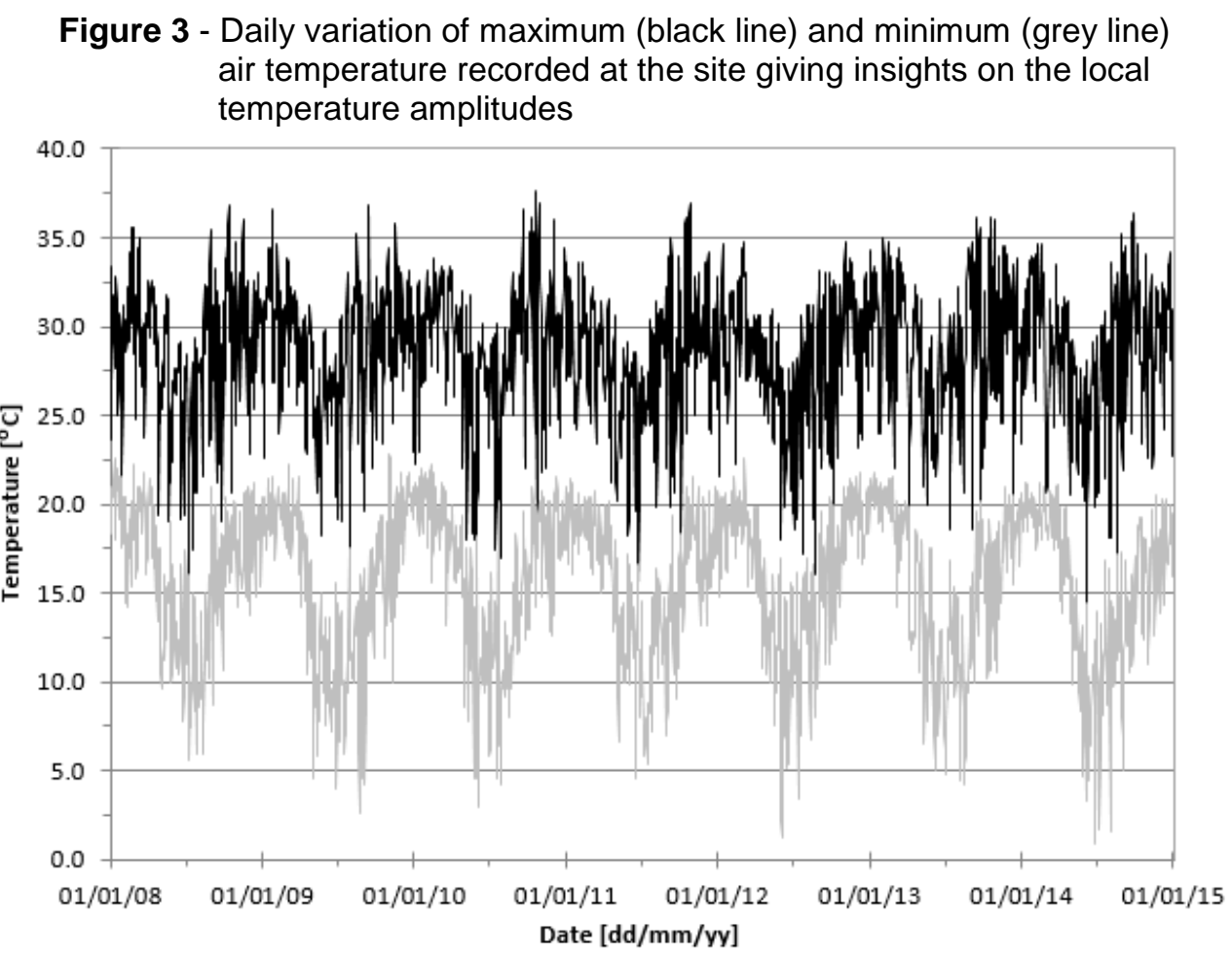

Temperatures showed a great variation over time, with minimum values being as low as $2.0^{\circ} \mathrm{C}$ and maximum as high as $38.0^{\circ} \mathrm{C}$. This already indicates a great variation in local ETP rates (also influencing groundwater recharge) since the air humidity will likewise change with these variations.

Different scenarios were built upon a first model run. Due to the great historical variation of rainfall rates, projections with different precipitation values were generated, so that it was possible to compare the resulting groundwater recharge rates for each simulated scenario. Accordingly, we can assess the effects of global changes (such as decreasing in rainfall - IPCC, 2021) in terms of aquifer recharge variations. The rainfall values were systematically decreased in different simulations to represent a mean decrease in overall rates. Furthermore, contrasting boundary conditions were implemented on the bottom of the domain to evaluate the effects of each choice on the resulted groundwater recharge. Different implementations allow for a representation of i) a free drainage at the bottom of the domain, or ii) a time varying saturated aquifer 
top, which represents water table fluctuations over time through an exponential function based on a reference mean water level; thus HYDRUS calculates the flux accordingly (HOPMANS; STRICKER, 1989). As demonstrated by Ernst e Feddes (1979), this deep drainage BC can be expressed by Eq.3, where empirical parameters $A$ and $B$ are $-1.8 \mathrm{~cm} / \mathrm{d}$ (the negative sign indicating a downward flux) and $-0.007 / \mathrm{cm}$ for B, respectively, and $h_{g w}$ is $800 \mathrm{~cm}$ (NETO et al., 2015).

$q_{L}(t)=A \exp \left[-B\left|h_{L-} h_{g w}\right|\right]$

$\mathrm{qL}(\mathrm{t})=$ flux $\mathrm{BC}$ of the model depending on time $[T]$;

$h \mathrm{~L}=$ hydraulic head in a given time $\mathrm{t}[\mathrm{L}]$;

$\mathrm{h}_{\mathrm{gw}}=$ mean hydraulic head for the model bottom [L];

A e $B=$ empirical parameters $\left[[\mathrm{L} / \mathrm{T}]\right.$ and $\left.\left[\mathrm{L}^{-1}\right]\right]$

Initial conditions were applied to the hydraulic head and distributed homogeneously throughout the profile, being equal to $-2 \mathrm{~m}$ (slightly unsaturated). Only an approximation of the initial conditions was required, since the simulations have started two years before the five years that were analyzed $(t=0)$. So that, in the beginning of the analyzed period (2010, $\mathrm{t}=730$ days) the soil moisture conditions were in balance and being the most consistent with the actual conditions at the site.

According to Šimůnek et al. (2012), HYDRUS-1D is based on physical models, so it requires little or no calibration once the input parameters are reliable and have a high level of representativeness. Several examples are found in the literature, in which such models were successfully applied in laboratory and field experiments using independently determined parameters (examples can be seen in Figure 4), that is, without any calibration (as listed by ŠIMU゚NEK et al., 2012, 2013). Therefore, the calibration of the model was not performed in this study since input values were based on field studies and were previously applied in other studies showing successful results (ALFARO SOTO et al., 2018; NETO et al., 2015). 
Figure 4 - Schematic section of a typical vadose zone of a soil profile and its hydrological components (not to scale)

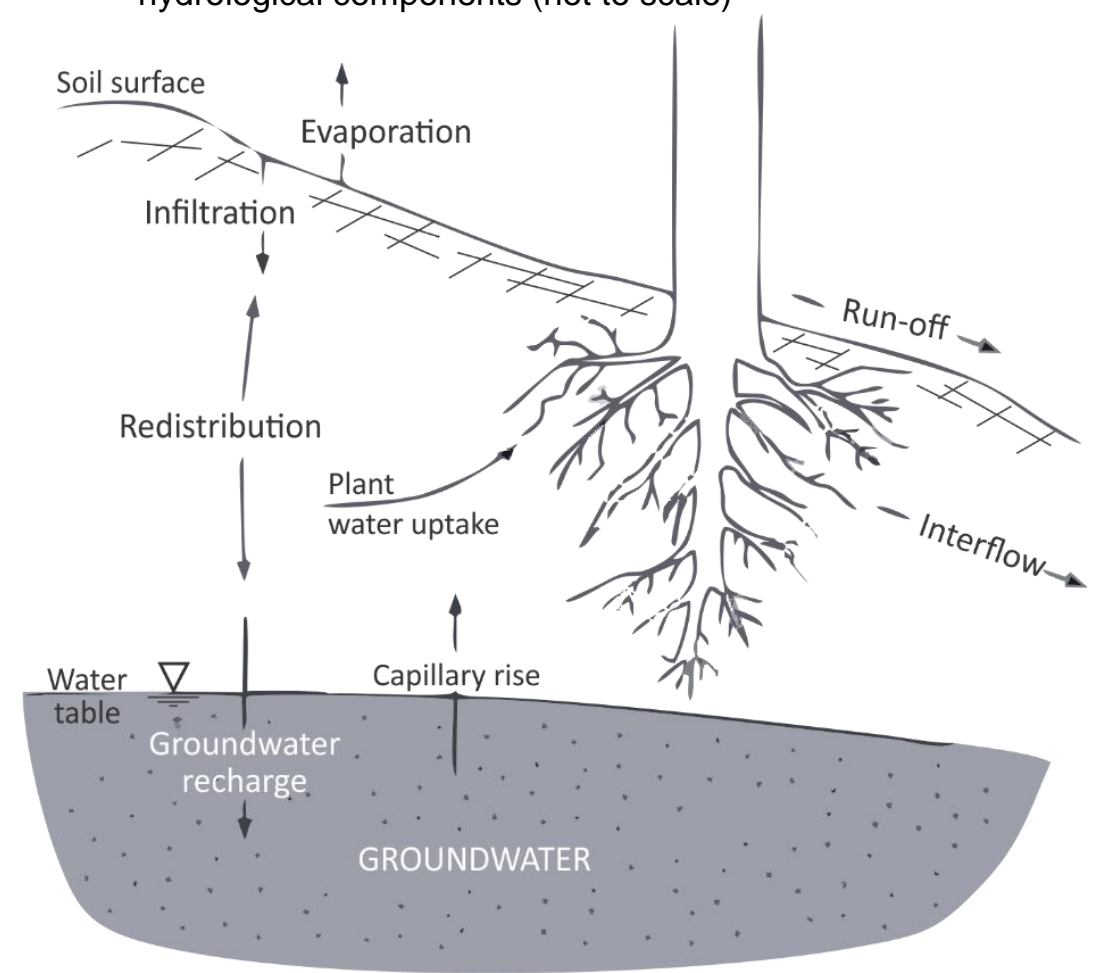

Source: Modified from Dingman (2002).

\section{RESULTS AND DISCUSSION}

\subsection{Hydraulic properties on the soil profile}

The analysis of how hydraulic properties varied on the soil profile over time, such as soil water content and hydraulic conductivity, is presented in this sub-section. The soil water content and its temporal variation are particularly showed in Figure 5a. The plot clearly shows that the first two meters below the ground surface present great variation in terms of volumetric water content over time. This phenomenon occurs because the water occupying this zone is directly affected by the climatic conditions imposed by atmospheric variations (such as evaporation), but also by water absorption from roots, especially occurring in the first meter of the soil surface. Below the first two meters of the soil profile, the overall variation in water content is more restricted, being affected only by the downward flow of water and its variation due to different influx from the root zone. 
Figure 5 - a) Variation in volumetric water content $(\theta)$ by soil depth - it is noted that the largest variation remains in the first two meters of the soil profile; $\mathbf{b})$ Variation in the unsaturated hydraulic conductivity $(\mathrm{K}(\theta)$ by soil depth; $\mathbf{c})$ Relationship between $\mathrm{K}(\theta)$ and $\theta$. Each line represents a given time $t$ simulated
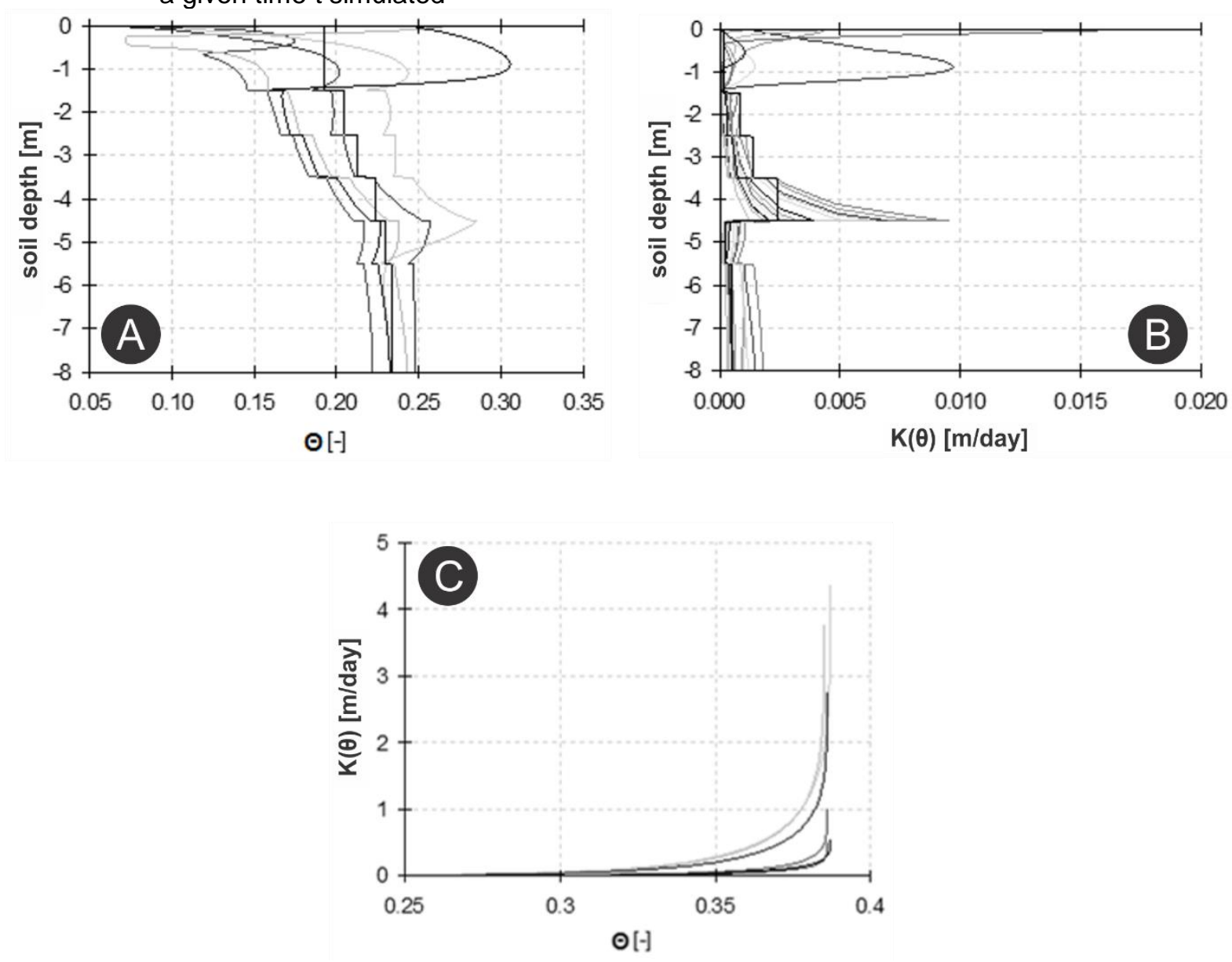

The Figure $5 \mathrm{~b}$ shows the resulting changes in values of non-saturated hydraulic conductivity $\mathrm{K}(\theta)$ of the soil profile that are related to the variation in soil water content (Eq.2). The main changes in the $\mathrm{K}(\theta)$ of the profile occur in the first meters near the surface due to large variation in the water content in this horizon. Great changes also occur between 3.5 and $4.5 \mathrm{~m}$ depth, where the soil composition is more sandy. Due to characteristics such as porosity and intrinsic lithotype permeability, this horizon also has a high variability in $\mathrm{K}(\theta)$. In periods when large rainfall amount takes place, for instance, the value of $K(\theta)$ has a significant increase in values. This fact indicates higher overall water velocities in this portion of the soil, which can greatly impact solutes transport and attenuation, eventually, since less time for reactions would be available in such conditions and layers. This is an issue that can be further assessed in next studies by making use of such models. That use and comparison would be valuable in order to understand the dynamics of possible contaminants in the area. 
The plot of Figure $5 \mathrm{c}$ is proper to observe the relationship between the volumetric soil water content $(\theta)$ and the $K(\theta)$. There is an exponential relationship between the parameters, with a sudden increase in $K(\theta)$ when the $\theta$ reaches 0.38 (maximum value of water content according to laboratory tests), and the saturated hydraulic conductivity can be as high as $100 x$ the value under unsaturated conditions. However, it is worth mentioning that during all the performed simulations, the maximum values of $\theta$ were in the order of 0.31 , as can be seen in Figure $5 a$.

\subsection{Groundwater recharge rates scenarios}

The first scenario considered a model with a free drainage condition, which neglects the presence of phreatic surface within model domain, thus there is a free water flow at the base. For this free drain model at the base, the calculated recharge rate was $405 \mathrm{~mm} /$ year for the simulated period of five years, which represents $28.9 \%$ of the average annual precipitation of the same period. The estimated value is close to the $340 \mathrm{~mm} /$ year computed in Neto et al. (2015). As seen in Figure 6, the highest recharge rates occurred between the years 2010 and 2012, following more intense precipitation rates on that period. We also observed that temperatures were slightly lower in those years, which possibly lead to a reduced evapotranspiration rates as well, thus resulting in higher infiltration rates to the soil below the root zone.

Figure 6 - Groundwater recharge rate (line) of the model with free drainage $\mathrm{BC}$ at the bottom alongside daily rainfall (bars)

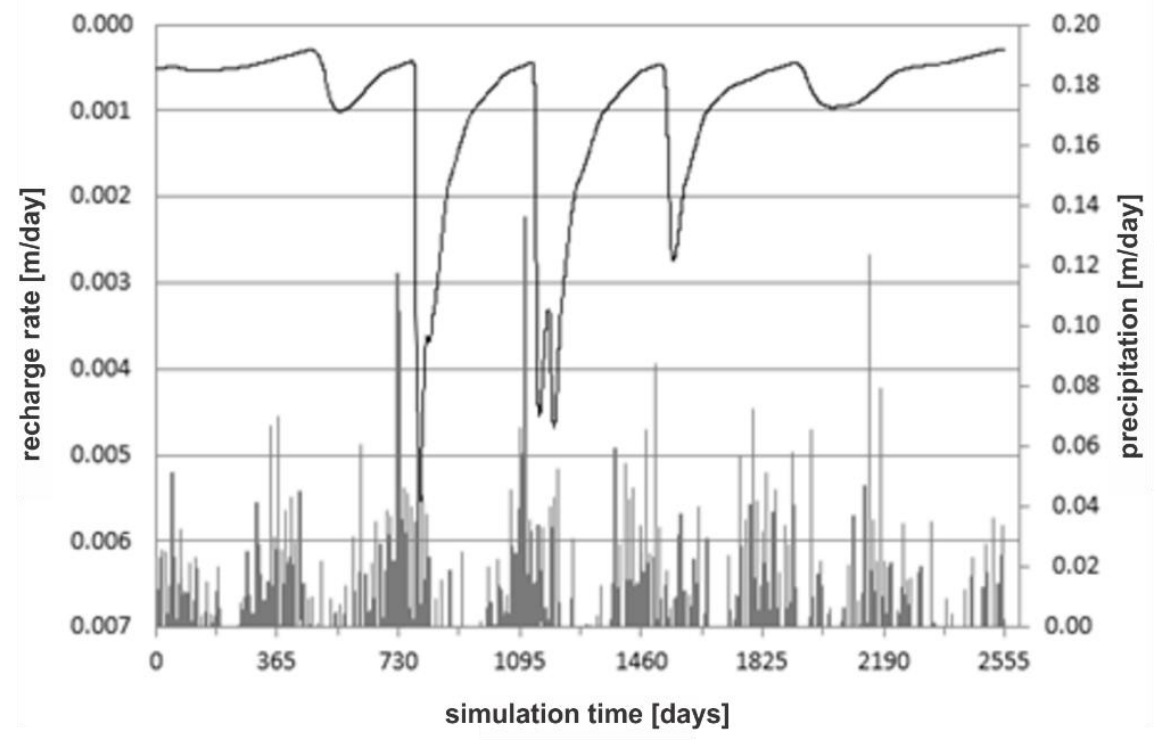


From Figure 6, it can be depicted that recharge occurs on average within a range of 90 days after the rain peaks, which can be translated as the averaged traveltime of infiltrating water through the vadose zone from soil surface. This fact is particularly observed in the year 2011 , when in $t=1110$ days a rain peak rate of 130 $\mathrm{mm} / \mathrm{d}$ occurred and the peak of the recharge took place after 88 days $(\mathrm{t}=1198$ days $)$. This value is similar to 87 days and 89 days reached in the previous studies of Neto (2006) and Neto et al. (2015), respectively. Although our results were in line with other studies in the area, a more accurate estimation of vadose-zone travel-times can be done with the help of natural environmental tracers in conjunction with solute transport simulations (SPRENGER et al., 2016), which was out of the scope of this study.

As a second scenario, we carried out simulations with a constant water table fixed at the bottom of the domain at the depth of $8.0 \mathrm{~m}$ below the soil surface, which represents the average local water table (NETO et al., 2015). In this case, the computed groundwater recharge rate of $400 \mathrm{~mm} / \mathrm{year}$ is slightly lower in comparison to the first scenario, representing $28.2 \%$ of the average annual precipitation, Figure $7 \mathrm{a}$. Still, patterns were very similar to the previous scenario. In this model, the average infiltration time was shorter when compared to the previous scenario with free drainage $\mathrm{BC}$ at the bottom of the model. Here, the travel-time was estimated between 30 and 60 days. This fact is explained by the close proximity between the soil surface and the top of saturated portion of the aquifer since the water table depth is in a fixed position and even in dry periods the water table does not drop.

Figure 7 - Comparison of groundwater recharge rates for models with free drainage BC (full black line) versus model with constant water table (dotted line) (a) and deep drainage (grey line) (b)
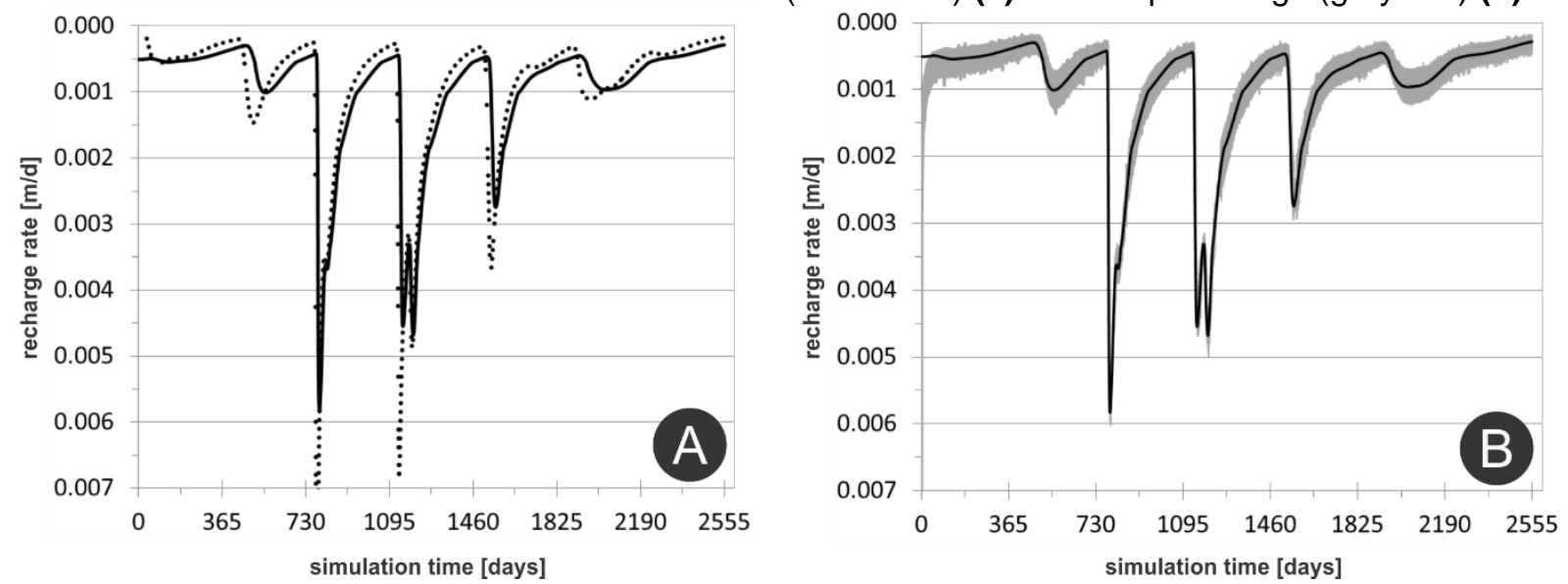
The third scenario has the implementation of the deep drainage $B C$ at the bottom of the domain in order to represent a temporal variation of the local water table. Nevertheless, as can be seen in Figure $7 b$, the computed groundwater recharge rates are very similar to those values of the first scenario, where a free drainage $B C$ was implemented, thus proving the applicability of the first model for the proposed objective. It is observed a larger variability on recharge rates in third scenario, which is the result of water table minor fluctuations that occur in time. Still, the recharge/precipitation ratio of this model is $28.2 \%$, with calculated recharge rate of $400 \mathrm{~mm} / \mathrm{year}$, similar values to those obtained in the first model runs.

Furthermore, considering the first scenario for a larger time-span (10 years), the computed recharge/rainfall ratio is similar (approximately $24 \%$ ), whereas the average recharge rate is calculated as $337 \mathrm{~mm} /$ year. The recharge rates distribution in this model shows similar patterns, as can be seen in Figure 8. It is similar to first model run with an approximate three-to-four years cycle with intervals of low groundwater recharge occurring (from 2005 to 2009, $t=365$ and $t=1825$ ) in between high recharge rates. This could be explained by atmospheric and meteorological cycles that can occur approximately every three-or-four years, resulting in higher rainfall rates and/or different ETP dynamics due to temperature fluctuations (GORDON, 1982). Future studies and modeling efforts could comprise larger time-periods and simultaneously carry spectral analyses of such signals, for instance, as well as cross correlation analyses of these patterns to identify and better understand how such cycles occur locally.

Figure 8 - Groundwater recharge rate (line) of the model for a 10 years run using the free drainage $\mathrm{BC}$ at the bottom alongside daily rainfall (bars)

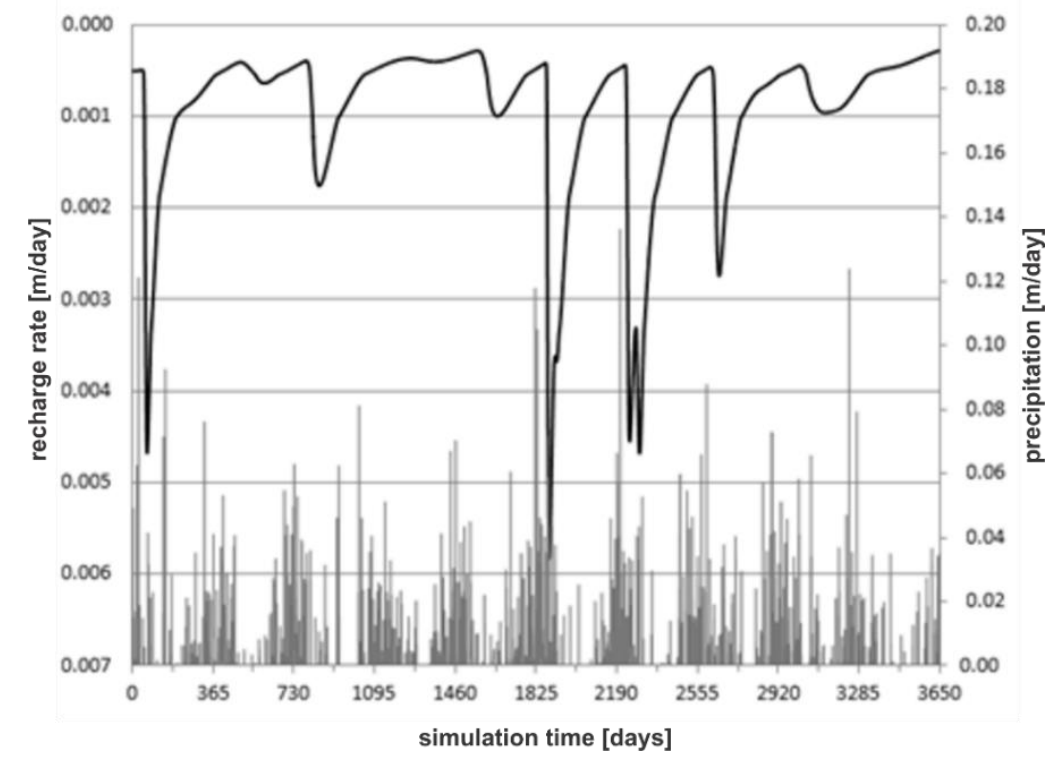

Holos Environment (2021), 21 (3): 402-422. 415 
In a last scenario, we assessed the effects of a paved cover on the ground surface. The purpose of this last simulation scenario is to check the dynamic behavior of recharge against different types of land use and occupation considering the soil that covers the recharge zones of phreatic aquifers. To this end, the plant cover was withdrawn from the model top and the first $0.20 \mathrm{~m}$ from the top of the model was replaced by a layer simulating concrete for paving and coverage in constructions and buildings. The van Genuchten parameters for the concrete are already stored on HYDRUS-1D database, according to the study of Schneider et al. (2010) for concrete of type $C-15 A$, Table 2 .

Table 2 - van Genuchten-Mualem hydraulic parameters for concrete layer applied in the model top

\begin{tabular}{ccccccc}
\hline Depth $(\mathbf{m})$ & Or & Os & $\boldsymbol{\alpha}\left(\mathbf{m}^{-1}\right)$ & $\mathbf{n}$ & $\mathbf{K}_{\mathbf{s}}(\mathbf{m} / \mathbf{d})$ & $\mathbf{L}$ \\
\hline $0-0,20$ & 0,000 & 0,070 & 0,000248 & 1,92 & $4.8 \mathrm{E}-11$ & 0,5
\end{tabular}

Source: Schneider et al. (2010).

To better visualize the results of this change on groundwater recharge processes, an observation point is inserted just below the generated concrete coverage, specifically at $0.21 \mathrm{~m}$ below the surface. The Figure 9 presents the temporal variation of volumetric water content $(\theta)$ at that point of observation just below the paved layer during a period of 7 years. Through the analysis of soil water dynamics it is possible to note that a constant drop in the $\theta$ values during the course of the whole simulation, pointing only to a loss of water in that place and no other water influx.

Figure 9 - Temporal variation of soil water content $(\theta)$ at the observation point inserted at $0.21 \mathrm{~m}$ depth in the soil profile containing the concrete surface cover. The systematically decrease in $\theta$ over time indicates the absence of groundwater recharge.

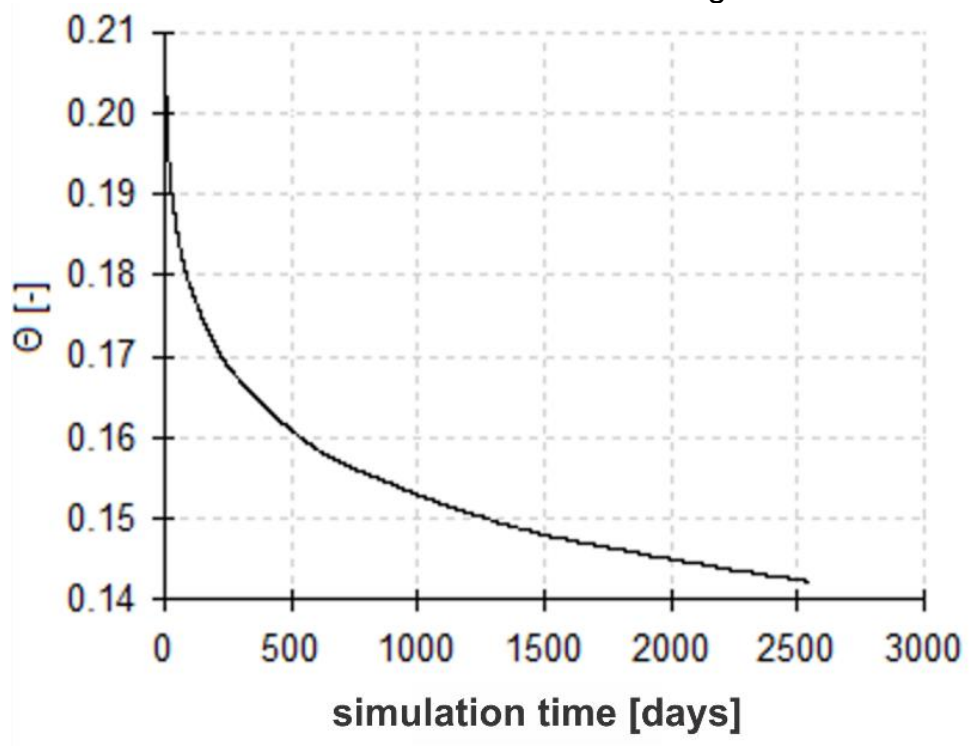


The constant drop in the water content at this point verifies that infiltration of water from rainfall does not occur occurring through the paved layer, which would result in the lack of groundwater recharge locally. Likewise, the hydraulic parameters of the entire modeling profile responded similarly, with an overall drop in water contents and $\mathrm{K}(\theta)$ values (data not shown), as expected.

\subsection{Groundwater recharge/precipitation projections}

Variation in precipitation rates over the months and years will result in different groundwater recharge rates for the local aquifer, since as the precipitation decreases, as consequence lower volumes of water infiltrate the soil and eventually reach the saturated zone. In order to evaluate the dependence and relationship between such parameters, different scenarios were analyzed with diverse daily precipitation rates within the simulated period. Among various scenarios, rates have been systematically reduced following projected scenario of reduced rainfall rates for the area (IPCC, 2021). In sum, precipitation rates were decrease to a certain percentage to simulate the continuous decrease in rainfall rates over time, for instance, as has been occurring in recent years in several Brazilian regions.

The overall results obtained from these simulations are presented in Figure 10a, in which we present the relationship between the applied variation in precipitation rates and the resulting cumulative groundwater recharge rate at the end of each simulated scenario. 
Figure 10 - a) relationship between changes in precipitation rates and the respective resulting decrease in recharge rates. The two fitted regression lines are also presented in the graph together with their coefficient of determination $\left(R^{2}\right)$; b) simulated recharge rates without variation in precipitation values (solid line) and with $10 \%$ decrease in values (dashed line)
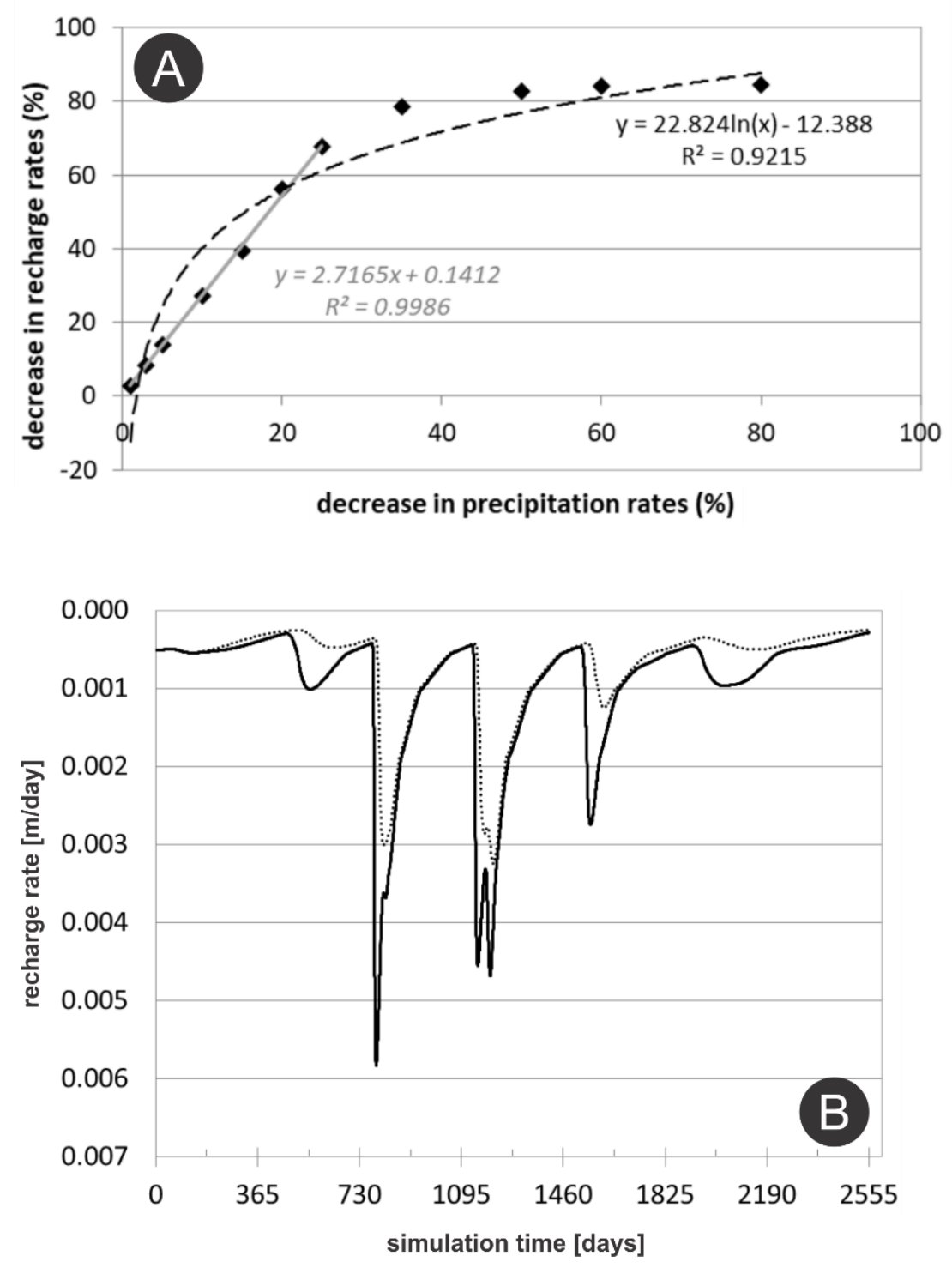

Results show that a decrease in precipitation rates would lead to an overall decrease in groundwater recharge rates, as expected. From the plot in Figure 10a, it can be observed that the fitted line and its calculated coefficient of determination $\mathrm{R}^{2}=0.9215$ pointing to a good adjustment of the line to the model results. This suggests a nonlinear relation between decreases in precipitation and resulting groundwater recharge. In a closer inspection, when we analyze the first part of the plot (decrease in precipitation up to $25 \%$ ) we can affirm that the relationship between precipitation and recharging is approximately 1 to 3 . The linear relation between model results and fitted line shows a very good coefficient of determination $\left(R^{2}=0.998\right.$, grey line on the plot). For instance, with the decrease of $1 \%$ in the precipitation rates, the decrease in 
recharge rates would be approximately $3 \%$. For comparison, in Figure 10b we show the resulting groundwater recharge patterns for the model with precipitation rates decreased in $10 \%$, together with the recharge patterns of the base case scenario.

Overall lower groundwater recharge rates were observed for the last model when compared to the first, especially at the beginning of $2010(t=730)$ when the highest recharge rates between the simulated years occurred. With a $10 \%$ decrease in rainfall, the recharge rate was approximately 30\% lower (down from $405 \mathrm{~mm} / \mathrm{year}$ to $283 \mathrm{~mm} /$ year). We emphasize that other climatic variations such as change in temperatures could equally pose an effect on the overall groundwater recharge rates since this would affect evaporation and ETP processes. Especially with mean global temperatures systematically increasing (ASADI ZARCH et al., 2017; IPCC, 2021), this would be an important parameter to be considered in future assessments alongside changes in precipitation rates.

\section{CONCLUSIONS}

The present modeling study aimed to enhance the current understanding the groundwater recharge dynamics of the Rio Claro aquifer and also considering scenarios of lower precipitation rates. Through one-dimensional numerical simulations developed with the HYDRUS-1D, it is possible to observe the spatio-temporal variations of unsaturated hydraulic conductivity values and soil moisture content, the former being directly proportional to the second. In addition, the mean infiltration time obtained by the simulations was between 85 and 90 days, which could be quicker in periods of rising capillary fringe. Moreover, the simulated recharge rates were around $20-30 \%$ of total precipitation, which highly varied in time depending on the actual precipitation rates. The average recharge rate was slightly higher than values computed in other studies carried out in the same aquifer (GONÇALVES et al., 2019, NOGUEIRA; KIANG, 2015).

Through additional performed scenarios, a logarithmic relationship between rainfall variations and overall groundwater recharge rates was observed. These simulations showed that for a decrease of up to $25 \%$ in precipitation rates, a relative decrease of 1:3 in groundwater recharge rates can be expected, which seems to be smaller with larger decreases in precipitation rates (above 25\% decrease). Once a concrete layer or pavement covers the soil surface, it has been shown that water 
infiltration is not expected. Likely, this does not imply in total absence of groundwater recharge of an aquifer since other water sources, such as leaks in water and sewage distribution networks in addition to small infiltration by cracks may contribute in terms of recharge inflow. To test such additional hypotheses and include in a recharge study, a greater range of data and knowledge about the area to be modeled is required. With the support of water sampling, laboratory and field tests, and also a systematic monitoring of parameters, the model responses are likely to be even more reliable and fruitful. Therefore, they may be further used for other projections and as an auxiliary tool for understanding hydrogeological processes such as contaminant transport and attenuation.

\section{REFERENCES}

ALLISON, G.B., GEE, G.W., TYLER, S.W. Vadose-Zone Techniques for Estimating Groundwater Recharge in Arid and Semiarid Regions. Soil Sci. Soc. Am. J. v. 58, p. 6-14. https://doi.org/10.2136/sssaj1994.03615995005800010002x

ASADI ZARCH, M.A., SIVAKUMAR, B., MALEKINEZHAD, H., SHARMA, A. Future aridity under conditions of global climate change. J. Hydrol. v. 554, p. 451-469.

https://doi.org/10.1016/i.jhydrol.2017.08.043

ALFARO SOTO, M.A., D.M. KUMAYAMA e C. H. KIANG. Calibração de um reflectômetro para estudos do fluxo de água em solo não saturado. Geociências (São Paulo), v.6, p.1-8. 2008.

BRANDENBURG, J. P. Geologic frameworks for groundwater flow models. 2020. 25 p. Disponível em: www.gw-project.org.

CARNIER NETO, D. Análise das séries temporais de monitoramento de nível d'água em poços no Aquífero Rio Claro, (Dissertação de Mestrado). Universidade Estadual Paulista, Instituto de Geociências e Ciências Exatas, Rio Claro (SP). 88 p. 2006.

DINGMAN, S.L. Physical hydrology. 2nd Edition. Upper Saddle River: Prentice Hall, 2002. $646 \mathrm{p}$.

DOS SANTOS, R. M., KOIDE, S., TÁVORA, B. E., \& DE ARAUJO, D. L. Groundwater recharge in the cerrado biome, Brazil-a multi-method study at experimental watershed scale. Water (Switzerland), v. 13, n. 1, p. 1-28, 2021. https://doi.org/10.3390/w13010020

ERNST, L.F., and R.A. FEDDES. Invloed van grondwateronttrekking voor beregening en drinkwater op de grondwaterstand (in Dutch). Nota 116, Instituut voor Cultuurtechniek en Waterhuishouding, ICW, Wageningen, Netherlands. 1979.

FEDDES, R.A., P.J. KOWALIK and H. ZARADNY. Simulation of field water use and crop yield. Simulation Monograph. Pudoc, Wageningen, the Netherlands. 1978. 
GENUCHTEN van, M. Th. A closed-form equation for predicting the hydraulic conductivity of unsaturated soils. Soil Science of America Journal, v. 44, n. 5, p.892-898, 1980.

https://doi.org/10.2136/sssaj1980.03615995004400050002x

GONÇALVES, R. D., \& CHANG, H. K. Condutividade Hidráulica da Formação Rio Claro a partir de ensaios granulométricos. Holos Environment, v. 18, n. 1, 44, 2018.

https://doi.org/10.14295/holos.v18i1.12249

GONÇALVES, R.D., TERAMOTO, E.H., ENGELBRECHT, B.Z., ALFARO SOTO, M.A., CHANG, H.K., VAN GENUCHTEN, M.T. Quasi-Saturated Layer: Implications for Estimating Recharge and Groundwater Modeling. Groundwater 1-9, 2019.

https://doi.org/10.1111/gwat.12916

GORDON, A.H. A Three year meteorological cycle. Weather Clim, v. 2, p. 22-24, 1982. https://doi.org/10.2307/44259540

HEALY, R.W. Estimating groundwater recharge. Cambridge University Press. 2010. https://doi.org/10.1017/CBO9780511780745

HEALY, R.W., COOK, P.G. Using groundwater levels to estimate recharge. Hydrogeol. J. 10, p. 91-109. https://doi.org/10.1007/s10040-001-0178-0. 2002.

https://doi.org/10.1007/s10040-001-0178-0

HARGREAVES, G.H. Moisture availability and crop production. Transactions of the American Society of Agricultural Engineers, v. 18, n. 5, p. 980-984, 1975.

https://doi.org/10.13031/2013.36722

HÖLTING, B., \& COLDEWEY, W. G. Hydrogeology. Springer Berlin Heidelberg, 2019. https://doi.org/10.1007/978-3-662-56375-5. https://doi.org/10.1007/978-3-662-56375-5

HOPMANS, J. W., and J. N. M. STRICKER. Stochastic analysis of soil water regime in a watershed. J. Hydrol., v. 105, p. 57-84, 1989. https://doi.org/10.1016/0022-1694(89)90096-6

IPCC. Climate Change 2021: The Physical Science Basis. Contribution of Working Group I to the Sixth Assessment Report of the Intergovernmental Panel on Climate Change.

Cambridge University Press, 2021.

NETO, D. C., CHANG, H. K. AND VAN GENUCHTEN, M. TH. A Mathematical View of Water Table Fluctuations in a Shallow Aquifer in Brazil. Groundwater, 2015.

https://doi.org/10.1111/gwat.12329

NOGUEIRA, G., STIGTER, T.Y., ZHOU, Y., MUSSA, F., JUIZO, D. Understanding groundwater salinization mechanisms to secure freshwater resources in the water-scarce city of Maputo, Mozambique. Sci. Total Environ., v. 661, p. 723-736.

https://doi.org/10.1016/j.scitotenv.2018.12.343

NOGUEIRA, G.E.H., KIANG, C.H. Simulação numérica de fluxo de águas subterrâneas do aquífero rio claro, porção nordeste do município de Rio Claro, SP. Águas Subterrâneas, v. 29, n. 175, 2015. https://doi.org/10.14295/ras.v29i2.28304

OLIVA, A. Estudo hidrofaciológico do Aqüífero Rio Claro no Município de Rio Claro SP. (Tese de Doutorado), Universidade Estadual Paulista, Instituto de Geociências e Ciências Exatas, Rio Claro (SP). 196 p. 2006. 
PERINOTTO, J. A J. et al. Nova Contribuição ao Conhe- cimento da Formação Rio Claro (T) na Folha Rio Claro (SP), Geociências, v.25, n.3, p.297-306, 2006.

RAIDLA, V., KERN, Z., PÄRN, J., BABRE, A., ERG, K., IVASK, J., KALVĀNS, A., KOHÁN, B., LELGUS, M., MARTMA, T., MOKRIK, R., POPOVS, K., \& VAIKMÄE, R. A $\delta 180$ isoscape for the shallow groundwater in the Baltic Artesian Basin. Journal of Hydrology, v. 542, 254267, 2016. https://doi.org/10.1016/i.jhydrol.2016.09.004

RICHARDS, L.A. Capillary conduction of liquids through porous mediums. Physics, n. 1. p. 318-333. 1931. https://doi.org/10.1063/1.1745010

SCHNEIDER, S. D. JACQUES, and D. MALLANTS. Estimating unsaturated hydraulic properties of concrete C-15-A and mortar M1, Restricted Contract Report SCK ${ }^{*}$ CEN-R5051, 10/SSc/P-57, 2010.

ŞEN, Z. Practical and applied hydrogeology. Elsevier. https://doi.org/10.1016/B978-0-12$\underline{800075-5.00001-7}$

ŠIMŮNEK, J., K. HUANG; VAN GENUCHTEN, M. TH. The HYDRUS code for simulating the one-dimensional movement of water, heat, and multiple solutes in variablysaturated media. Version 6.0, Research Report No. 144, U.S. Salinity Laboratory, USDA, ARS, Riverside, California, 1998. 164p.

ŠIMU゚NEK, J., M. ŠEJNA, H. SAITO, M. SAKAI, and M.TH. VAN GENUCHTEN. The HYDRUS-1D software package for simulating the one-dimensional movement of water, heat and multiple solutes in variably-saturated media, Version 4.08, HYDRUS Software Series 3, Dept. of Environ. Sciences, Univ. of California, Riverside, CA. 2008. https://doi.org/10.13031/2013.42247

ŠIMŮNEK, J., VAN GENUCHTEN, M. TH.; ŠEJNA, M. Hydrus: model use, calibration, and validation. Soil \& Water Division of ASABE, v. 55, p 1261-1274, 2012.

ŠIMU゚NEK, J., M. ŠEJNA, H. SAITO, M. SAKAI; VAN GENUCHTEN, M. TH. The HYDRUS1D Software Package for Simulating the Movement of Water, Heat, and Multiple Solutes in Variably Saturated Media, Version 4.16, HYDRUS Software Series 3, Department of Environmental Sciences, University of California Riverside, Riverside, California, USA, pp. 340, 2013.

SISTEMA DE INFORMAÇÕES PARA O GERENCIAMENTO DE RECURSOS HÍDRICOS DO ESTADO DE SÃO PAULO (SigRH-SP), 2014. Disponível em: www.sigrh.sp.gov.br.

SPRENGER, M., SEEGER, S., BLUME, T.; WEILER, M. Travel times in the vadose zone: Variability in space and time. Water Resources Research, v. 52 , n. 8, p. 5727-5754.. https://doi.org/10.1002/2015WR018077

SU, N. A formula for computation of time-varying recharge of groundwater. Journal of Hydrology, v. 160, p. 123-135, 1994. https://doi.org/10.1016/0022-1694(94)90037-X 